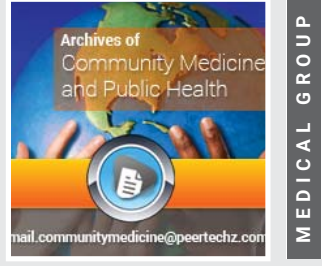

\title{
COVID-19 pandemic wave: A global struggle and ways to
} control

Received: 10 August, 2020

Accepted: 18 August, 2020

Published: 20 August, 2020

*Corresponding author: Asem Surindro Singh, PHD, Scientist, Department of Pathology, University of Mississippi Medical Centre, Jackson, Mississippi, USA, E-mail: asemsuren@gmail.com

https://www.peertechz.com

\author{
Asem Surindro Singh ${ }^{1 *}$ and Machathoibi Chanu \\ Takhellambam ${ }^{2}$ \\ 'Department of Pathology, University of Mississippi Medical Centre, Jackson, Mississippi, USA \\ ${ }^{2}$ Department of Biotechnology, Manipur University, Canchipur, India
}

Check for updates

\begin{abstract}
COVID-19 is currently world's most dangerous disease. According to the latest worldometer data, COVID-19 has infected almost 22 million people living across the world, since its outbreak in January 2020. Out of the 22 million, 0.77 million had died and over 14 million have recovered; and more than 64 thousands of people are living at critical condition. It has greatly affected normal lives of the people, free movement, social interaction, education, business and many more. Every nation is paying full attention on fight against the disease. This review is a brief highlight on this current issue and discuss on how we can overcome this raging transmission of COVID-19.
\end{abstract}

\section{Together we can work to control the force of COVID-19 wave!}

The pandemic disease COVID-19 (coronavirus disease 2019) is caused by SARS-CoV-2 (severe acute respiratory syndrome coronavirus 2). It has led several thousands of deaths across the globe within a few months time [1-3]. Since the identification of the disease at first in December 2019 at Wuhan, Hubei, China; the disease has been exploding throughout the planet. It may be noted that the first confirmed case had been further traced back and indeed it was found to have been confirmed already in November 2019 in Hubei, rather than December, one month earlier than the previous report [4]. Many experts believed that the disease outbreak might have been under controlled if the report was published in November 2019, as soon as the case was confirmed. Counting from the time of outbreak of the disease through the third week of August 2020, over 0.77 millions of human lives (from 188 countries and territories) had been claimed to death by the deadly virus, [5,6]. Meanwhile, more than 13.7 million infected people have recovered from the disease so far $[5,6]$.

Since the COVID-19 has become pandemic and a life threatening disease to all human, the whole world is fighting to get rid of the disease which is solely needed. Most individuals who had lost their lives with COVID-19 infection, usually had histories of other prior/ current health issues such as hypertension, diabetes mellitus, respiratory/ cardiovascular diseases and/ or other health problems $[7,8]$. It thus appears that those death victims with COVID-19 might have overcome the death if they were free from the other health issues. On the other way round, without COVID-19, they might have survived through with those health issues. It was also reported that, even after the recovery, a normal health cannot be guaranteed if once suffered with COVID-19, as some individuals were found to have lungs damage and $20 \%$ to $30 \%$ reduced lungs capacity [9]. Thereby, once a person is infected by COVID-19, either death or less chances of having a normal healthy life may be warranted. Eventually, it is an urgent need to fight and get rid of COVID-19 from this planet at the earliest possibility. This requires immense contribution from all over the world.

Currently many vaccines of COVID-19 are on the process of development or under clinical trials [10-13]. Considering the past experience, availability of a reliable vaccine may not happen in the next some weeks, but possibly by next year 2021 [14]. It requires thorough testing, preparing animal models and systematic clinical trials, and moreover there are chances of mutation of the virus in adapting to animal and then to human which makes the challenge even harder. In the past, successful 
development of a vaccine had taken two to five years. But this time, the expected duration is much shorter, due to team work among the laboratories across many countries [14]. Therefore, it is highly essential for every single person in the world to be aware of the present situation and follow the preventive measures. Taking this as personal responsibility by every single person in the world will help in preventing himself or herself and others from transmission and infection of the disease. The guidelines provided by WHO and CDC include 1) to wear mask in public places, 2) frequent washing hands using soap and water rubbing hands for at least 20 seconds, 3) to avoid touching eyes, nose and mouth with unwashed hands 4) to cover nose and mouth when coughing or sneezing with tissue or mask and dispose it after used, 5) to keep distance from others 6) to stay away from crowded places and 7) to stay at home as much as possible [15-17]. Practicing these guidelines will help in decreasing the spread of transmission/ infection of the disease and thereby in flattening the current global epidemic peak of CPVID-19. On the fight against COVID-19, the current global economy is shrinking and people's normal live is turning into an unusual way. It has hampered students from going to schools, colleges and universities as all the institutions were locked down and many institutions have been used as quarantine centers. Both private and public sector businesses have been drastically going down. Nonetheless, sustaining life through these difficulties is more important than normal functioning of all these at the risk of losing lives. Where there is no life, there is no need of education, entertainment, earning etc. "To live" would need to come first. Therefore, it is one's responsibility to take care of oneself and for others, thereby saving the world.

\section{Why the pandemic wave continues forcing in many countries lately?}

Sitting on the roof top and looking down from it, hearing and imagining the present scenarios and thinking of the way COVID-19 is spreading like wild fire, unbearable suffering and dying of several thousands of people all over the world due this disease, is an overwhelming tragedy. Among the highest COVID-19 positive countries, like India, Brazil and USA, the epidemic peak continues to be inclining, even after many news have alerted the deadly pandemic spread of the virus. The great tragedy is that the virus continues to claim many more precious lives. It indicates deficit in public awareness, government policies and responsibilities to prevent the spread of the virus. Much could have been learned earlier from the other countries like Japan, China, Norway, which have immensely minimize or flatten the spread of the disease. Many experts have argued that delayed report released from China, where the virus was originated, would probably be the reason for this pandemic spread of the virus $[18,19]$. Keeping this argument aside and forgoing to the priority issue; it has been reported that early detection and isolation or reduced contact with people, in combination with the country's banning on intercity travels, have played a major role in controlling COVID-19 spread in China. Otherwise the disease spread in the country would have been increased by 67 -fold that led to the assumption of having nearly 8 million infected cases by the end of February in China, which is five times as many infections by the end of February 2020 [18-20].

\section{Can we control COVID-19 pandemic: A lesson to be lear- ned from Japan}

Japan is a densely populated country which is geographically close to China. Based on the country wise population density ranking Japan is placed at $11^{\text {th }}$ position in the world [21]. The country had been stormed by COVID-19 pandemic during the early outbreak of the disease. Japan has controlled the pandemic wave at the very early stage [22]; a thing that may be noted and learned. The key or strategy adopted by Japan in controlling the pandemic wave was to detect the outbreak and respond early, and understanding the transmission dynamics through field investigations [23]. Through cluster investigation, major environmental risk factors leading to clusters were recognized. They called the clusters as "three Cs" in short form, which represents 1) closed, 2) crowded spaces and 3) close contact. Japanese government introduced a slogan "avoid three Cs" since early March 2020, which supposedly played a major role in delaying the epidemic peak in their country [23]. As a discipline country, majority of the people kept their efforts to stay at home; and using protective face mask was customary for everyone. Moreover, schools, shopping centers were remained closed in major cities during the emergency state of the country [23]. Their successful control of COVID-19 rage looks to have an effective working with the "cluster-focused" approach. Now the people in Japan are slowly returning to normal life. One may argue that why "cluster-focused" would be more effective than tracking the people who have contacted with the COVID-19 positive cases. It is assumable that many patients may be reluctant to disclose the full information; and calling the patients and asking them to provide the names of the people they have contacted within the last fortnight, would be time consuming effort [23]. Considering the speed of transmission of the disease and finding cases through testing individuals who had contacted the patients and taking precautions/ preventive measures thereafter would be particularly ineffective to act early and timely to stop the transmission of the disease. It was also revealed that while many patients did not transmit to anyone, some had infected many; this results in forming "clusters" of infected persons as a single source [23]. Therefore, in addition to contact tracking, retrospective tracking of linked information between patients further helps in finding unrecognized cases that surround possible sources and thereby identifying clusters. Besides identifying the clusters, monitoring the number of unlinked cases helps in early detection of exponential growth of COVID-19 patients' number. This strategy had enabled the government of Japan to provide an effective warning to their people towards the resistance of COVID-19 pandemic wave in their country [23]. It appears that Japan fetched a second outbreak in March 2020 that led to a much higher number of positive cases (https://www. mhlw.go.jp/content/10900000/000620826). But the country was proud to see the result of effective working with "clusterfocused" approach; they declared that Japan had controlled the widespread of disease in May 2020 (https://www.sciencemag. org/news/2020/05/japan-ends-its-covid-19). Latest report

Citation: Singh AS, Takhellambam MC (2020) COVID-19 pandemic wave: A global struggle and ways to control. Arch Community Med Public Health 6(2): 179-185. 
(17 August 2020) showed, 1088 deaths with COVID-19 in Japan [24], which is about 300 more counting from March, further reveals that their strategy is successfully working.

\section{What has gone wrong with the countries with unstop- pable raging of COVID-19?}

As per the latest report of August 2020, Japan had reported 42263 positive cases; out of which 1026 cases were death [24]. Noting that the country was hit by pandemic wave during mid January 2020 [25], which happened earlier than many other countries, the number of COVID-19 positive and death cases are far too low when compared with the top three highest COVID-19 positive countries in the world. The top three countries are $1^{\text {st }}$ USA, $2^{\text {nd }}$ Brazil and $3^{\text {rd }}$ India. Within the same month (January 2020) Japan, USA and India was hit by the COVID-19 wave; and it started few weeks later for Brazil (February end 2020) [2628]. The latest report recorded that USA has 5582863 positive cases and 173339 deaths, Brazil with 3343925 positive cases and 108054 deaths and India with 2701572 positive cases and 51923 [24].

One may ask what went wrong with these countries. There are many more countries which are not mentioned here as it would have a more or less similar situation. Unlike Japan and some other countries which have controlled the COVID-19 outbreak, USA went through the other way round. Many news reports have criticized USA government for failing to contend the outbreak. After COVID-19 intrusion, the USA administration initially declared a public health emergency. Then, entry of most foreign nationals who recently traveled to China was prevented, but not the USA residents. There was no implementation for virus testing during screening of the persons who were seeking to enter the country $[29,30]$. The USA's initial response to the pandemic was arguably slow, considering preparation of healthcare system, restriction to travel or the testing for the virus etc [31-33]. The Centers for Disease Control and Prevention (CDC) warned the American public on February 25 for the first time, to prepare for a local outbreak [34]. Food and Drug Administration (FDA) began to allow public health agencies and private companies to develop and administer COVID-19 tests and allowed anyone to test for the disease following doctor's advice in early March 2020 [35]. The American president declared a national emergency on March 13 [36] and the country's administration largely waited until mid-March to start purchasing large quantities of medical equipments [37]. In early May, rigorous testing was conducted (6.5 million approx., about 250,000 per day) [38]; but that was not arguably not at the sufficient level to contend the outbreak [39]. These actions taken in the USA were too late after knowing speed and mode of the disease transmission. There were large gatherings before the rules came to effect for social distancing and large shutdowns. Indeed, these factors could accelerate the disease transmission in the USA [40].

India's response to control the COVID-19 outbreak was also particularly late, having already confirmed positive cases with the travel history coming from Wuhan, China, in January. The lockdowns and travel restriction were imposed only in March
2020, after the transmission began to rise [41,42]. Religious travels and congregations took place until March, which was believed to be a tremendous spreading device of this virus in the country [43-45]. Apart from this, several suspected cases were reported to have escaped from the quarantines centers and hospitals $[46,47]$ and many people broke the self isolation or quartile rules [48-50]. Thus, apart from government's late actions, lake of self discipline of many people was potentially leading to the current uncontrollable outbreak of COVID-19 in India.

The story is even more unpleasant in case of Brazil. Even after continued rise of COVID-19 positive cases and the deaths in Brazil, the country's President removed the minister of health disagreeing over the social distancing guidelines and appointed another health minister in order to favor reopening businesses at the earliest possibility [51-53]. Now Brazil stands second in the world with highest COVID-19 cases and deaths connected with the disease [54].

\section{Other countries that have contented or controlled sprea- ding of COVID-19}

COVID-19 virus began spreading in Norway by the end of Februrary 2020 [55]. The country performed rigorous testing [56] and without much delay, a national lockdown was announced in early March; schools, kindergartens, fitness centres, hair salons, sports/cultural events and gatherings were banned, while restrictions were applied to the restaurants [57]. Moreover, visits to Norway through Oslo airport was also banned while allowing Norwegian/Nordic citizens, foreign residents living in Norway and people continuing to another country; other people were discharged and quickly sent home and quarantine until then [58]. The country reported its second and third deaths caused by COVID-19, on $14^{\text {th }}$ March 2020 [59]. Then, just by two days ( $16^{\text {th }}$ March, 2020) the band was extended to all Norway boarders and Nordic non-Norwegian citizens, but domestic travels were not restricted [60]. This timely taken rigorous actions by Norway government have let the country to control the pandemic outbreak of COVID-19 at the early stage $[61,62]$. Similar pattern was also followed in Denmark, and so far the country had reported 15,740 confirmed cases, out of which 621 people had died due to the virus [24,63].

\section{Whether the outbreak continues uncontrollable, a thing to be learned from Italy}

Italy had confirmed its first COVID-19 case on $31^{\text {st }}$ January 2020 [64]. On the day itself, Italy government suspended all flights flying back and forth to China and declared a state of emergency [65]. Since day one, the country had taken extreme preventive measures with "cluster-based" approach [66]. The country was in forefront in Europe in taking stringent precautionary measures such as immediate declaration of state emergency and performing thermal scanning and checking temperatures on international passengers who arrived at Italian airports etc. $[65,67]$. Until mid February, Italy had just three confirmed positive cases [68]. Through an unexpected incident, the outbreak began about the end of February 2020 in Lombardy, a most populous, richest and most productive

Citation: Singh AS, Takhellambam MC (2020) COVID-19 pandemic wave: A global struggle and ways to control. Arch Community Med Public Health 6(2): 179-185. 
region in Italy. In the mid February, a 38 year old man was misdiagnosed with influenza which was later confirmed to be COVID-19; both the man and his pregnant wife were positive of the disease [69]. Initially there was no suspicion of COVID-19, no additional precautions were taken; and the man infected other patients and health workers in the hospital [70]. The patient had an active social life in the weeks before the illness and possibly had interacted with several people before spreading the virus to the hospital $[69,70]$. It was believed that this case might have linked to the first European local transmission occurred in Munich, Germany, during mid January 2020 [71]. By the end of February 2020, Lombardy had several thousands of positive cases which by large made up the most of Italy's positive cases [72]. At March end, the pandemic had reached its peak level in Italy with over one million positive cases and over 12 thousand deaths. Thousands of positive cases and hundreds of deaths were reported everyday [73, 24]. It was indeed a nightmare for the country and the fear wave spread all over the world. But now the panic is even greater in many other countries and USA is most terribly affected as its total number of death and positive cases (death cases $=>173339$ and positive cases $=>5.5$ million) far exceeds from the total positive cases of Italy and several other countries [24]. So far, Italy has reported over 0.25 million positive cases and over 35 thousand deaths linked to the COVID-19 virus infection [24]. After May 2020, the positive cases in Italy gradually decreased to a few hundred or closed to one hundred while the death numbers were close to one hundred or just a few; this has been consistent for the last three months [24]. This is the result of Italy's sincere and constant labor in fighting against COVID-19; a great lesson to the world. To come to this state, Italy had announced a series of stringent measures such as, national lockdowns, banning everything from shops to strolls in the parks, schools and universities and all non-essential economic activities (except pharmacies and food markets). Social distancing and use of masks were nicely practiced by everyone. Testing and contacttracing were performed effectively well [74]. Now the country is hopeful to control the COVID-19 pandemic.

\section{Recalling historical facts on many epidemic/ pandem- ic diseases that had ended millions of lives across the world in past centuries}

Killing of several thousands or millions of people due to contagious disease epidemic or pandemic is not new to this present world anymore. Even before the birth of Lord Jesus Christ, historical accounts had witnessed killing several thousands of people by epidemic diseases. For example, "Plague of Athens" had killed 75000-100000 people from Greece, Libya, Egypt and Ethiopia during 429 to $426 \mathrm{BC}$,

Table 1: Recalling historical records of past contagious epidemic/ pandemic diseases that had killed millions of people.

\begin{tabular}{|c|c|c|c|c|c|c|}
\hline SI. No. & $\begin{array}{l}\text { Epidemic/ } \\
\text { Pandemic }\end{array}$ & Year & Country & Disease & Death toll no. & Reference \\
\hline 1 & Antonine Plague & $\begin{array}{l}165-180 \text { (possibly } \\
\text { up to 190) }\end{array}$ & Roman Empire & $\begin{array}{l}\text { Unknown (suspected to be } \\
\text { smallpox) }\end{array}$ & 5-10 million & [78] \\
\hline 2 & Plague of Cyprian & $250-266$ & Europe & $\begin{array}{l}\text { Unknown (suspected to be } \\
\text { smallpox) }\end{array}$ & 1 million + & {$[79,80]$} \\
\hline 3 & Plague of Justinian & $541-549$ & Europe and West Asia & $\begin{array}{l}\text { Bubonic plague (beginning of } \\
\text { first plague pandemic) }\end{array}$ & $\begin{array}{l}25-100 \text { million ( } 40-50 \% \text { of } \\
\text { population of Europe) }\end{array}$ & {$[81,82,83]$} \\
\hline 4 & Japanese smallpox epidemic & $735-737$ & Japan & Smallpox & $\begin{array}{c}2 \text { million (approx. 1/3 of } \\
\text { Japanese population) }\end{array}$ & {$[84,85]$} \\
\hline 5 & $\begin{array}{c}\text { Black Death (start of the Second } \\
\text { plague pandemic) }\end{array}$ & $1346-1353$ & $\begin{array}{c}\text { Europe, Asia and } \\
\text { North Africa }\end{array}$ & $\begin{array}{c}\text { Bubonic plague (Yersinia pestis } \\
\text { bacterium) }\end{array}$ & $\begin{array}{l}75-200 \text { million }(10-60 \% \text { of } \\
\text { European population) }\end{array}$ & [86] \\
\hline 6 & Mexico smallpox epidemic & $1519-1520$ & Mexico & Smallpox & $5-8$ million ( $40 \%$ of population) & {$[87]$} \\
\hline 7 & Cocoliztli Epidemic & $1545-1548$ & Mexico & $\begin{array}{l}\text { Suspected to be Salmonella } \\
\text { enterica }\end{array}$ & $\begin{array}{l}5-15 \text { million ( } 80 \% \text { of } \\
\text { population) }\end{array}$ & [88-91] \\
\hline 8 & Cocoliztli epidemic & $1576-1580$ & Mexico & $\begin{array}{l}\text { Suspected to be Salmonella } \\
\text { enterica }\end{array}$ & $\begin{array}{l}2-2.5 \text { million }(50 \% \text { of } \\
\text { population) }\end{array}$ & [88-91] \\
\hline 9 & Naples Plague & 1656 & Italy & Bubonic plague & 1.25 million & {$[92]$} \\
\hline 10 & Persian Plague & $1772-1773$ & Persia & Bubonic plague & 2 million+ & [93] \\
\hline 11 & Third cholera pandemic & $1846-1860$ & Russia & Cholera & 1 million+ & [94] \\
\hline 12 & Third plague pandemic 12 & $1855-1960$ & Worldwide & Bubonic plague & $\begin{array}{l}12 \text { million+ in India and China } \\
\text { alone }\end{array}$ & {$[95,96]$} \\
\hline 13 & 1889-1890 flu pandemic & $1889-1890$ & Worldwide & Influenza & 1 Million & {$[97]$} \\
\hline 14 & $\begin{array}{l}1915 \text { Encephalitis lethargica } \\
\text { pandemic }\end{array}$ & $1915-1926$ & Worldwide & Encephalitis lethargic & 1.5 million & [98] \\
\hline 15 & $\begin{array}{c}1918 \text { influenza pandemic } \\
\text { ('Spanish flu') }\end{array}$ & $1918-1920$ & Worldwide & Spanish Flue & 17-100 million & {$[99-101]$} \\
\hline 16 & $\begin{array}{c}\text { 1918-1922 Russia typhus } \\
\text { epidemic }\end{array}$ & 1918-1922 & Russia & Typhus & 2.5 million & [102] \\
\hline 17 & $\begin{array}{l}\text { 1957-1958 influenza pandemic } \\
\text { ('Asian flu') }\end{array}$ & 1957-1958 & Worldwide & Influenza A virus subtype H2N2 & 1-4 million & {$[103,104]$} \\
\hline 18 & Hong Kong flu & $1968-1970$ & Worldwide & H3N2 virus & 1-4 million & {$[105,106]$} \\
\hline 19 & HIV/AIDS pandemic & 1981-present & Worldwide & HIV/AIDS & $\begin{array}{c}32 \text { million+ (23.6-43.8 million) } \\
\text { (data as of } 2018)\end{array}$ & {$[107,108]$} \\
\hline
\end{tabular}


through causing possibly typhus, typhoid fever or viral hemorrhagic fever etc. [75-77]. Records after the birth of Lord Jesus Christ, showed even more people dying across the world due to pandemic/ epidemic outbreak of contagious diseases. The following diseases may be named that had led to death of millions of people through the past centuries of years - Antonine Plague (2nd century), Plague of Cyprian (3rd century), Plague of Justinian ( $5^{\text {th }}$ century), Japanese smallpox epidemic ( $7^{\text {th }}$ century), Black Death ( $13^{\text {th }}$ century), 1520 Mexico smallpox epidemic ( $15^{\text {th }}$ century), Cocoliztli Epidemic $\left(15^{\text {th }}\right.$ century), Cocoliztli epidemic (15 $5^{\text {th }}$ century), Naples Plague (16 ${ }^{\text {th }}$ century), Persian Plague ( $17^{\text {th }}$ century), Third cholera pandemic ( $18^{\text {th }}$ century), Third plague pandemic ( $18^{\text {th }}$ century), flu pandemic (18 ${ }^{\text {th }}$ century), Encephalitis lethargica pandemic ( $19^{\text {th }}$ century), influenza pandemic 'Spanish flu' ( $19^{\text {th }}$ century), Russia typhus epidemic ( $19^{\text {th }}$ century), Influenza pandemic 'Asian flu' (19 $9^{\text {th }}$ century), Hong Kong flu ( $19^{\text {th }}$ century), HIV/ AIDS pandemic (1981-present). Among them, "Black Death" which occurred during 1346-1353 AD claimed 75-200 million of human lives in Europe, Asia and North Africa. The fatality rate was estimated be $10-60 \%$ of European population. On the other hand, the HIV/AIDS transmission is still on the slow move, even after its pandemic had claimed more than 23 million of lives over the last three decades, since its outbreak in 1981. However, with the advancement of medical science, development in healthcare care system and public awareness, there is no more panicking of the disease. Further summary about the outbreak of these diseases are provided in the Table 1 below with reference [78-108]. As per the reports, there were many other contagious disease epidemics/ pandemics that had ended several thousands and near million lives that are not described in this review.

\section{Conclusion}

Several past incidences of epidemic/ pandemic disease outbreaks had witnessed dying of several thousands and millions of people across the world. The world is still helpless when another epidemic/ pandemic wave storms again. In the past, the situation was much more horrifying as there was poor medical facility; once infected there is minimal chance of surviving. Thanks to the development of medical science, several millions have recovered in the case of COVID-19 pandemic that the whole world is facing now. Nonetheless, how about the 0.77 million lives that had ended due to suffering from COVID-19 and several others living under critical condition? Considering the current scenarios, some countries controlling the rage of the disease and some countries not, there seem to be lake of proper and timely management and conduct and understanding, that could lead to the failure. The best thing to do is we learn from those who successfully control the disease, the strategic methodologies and techniques that have been applied into it. The world is much smaller now in terms of technology and transport development; at high speed, COVID-19 can reach all over the world which is happening now. Therefore, a collective effort from every country is required in order to stop this disease; be in the enforcement of preventive measures, be in the development of an effective treatment or vaccine. Because, it is unlikely that a single country could stand alone and remain free from this pandemic disease.

\section{References}

1. Coronavirus disease (2019) (COVID-19)-Symptoms and causes. Mayo Clinic. Link: https://mayocl.in/3hcCOLo

2. Hui DS, I Azhar E, Madani TA, Ntoumi F, Kock R, et al. (2020) The continuing 2019-nCoV epidemic threat of novel coronaviruses to global health-The latest 2019 novel coronavirus outbreak in Wuhan, China. International Journal of Infectious Diseases 91: 264-266. Link: https://bit.ly/3gcroWs

3. WHO (2020) Director-General's opening remarks at the media briefing on COVID-19. World Health Organization (WHO). Link: https://bit.ly/2YdE8WO

4. Ma J (2020) Coronavirus: China's first confirmed Covid-19 case traced back to November 17. South China Morning Post. Link: https://bit.ly/3iSOWI8

5. COVID-19 Dashboard by the Center for Systems Science and Engineering (CSSE) at Johns Hopkins University (JHU). ArcGIS. Johns Hopkins University.

6. Novel Coronavirus (COVID-19) Situation Report - 191 (PDF). WHO

7. WHO (2020) Director-General's statement on the advice of the IHR Emergency Committee on Novel Coronavirus. World Health Organization (WHO). Link: https://bit.ly/3hfg8dA

8. Palmieri L, Andrianou X, Barbariol P, Bella A, Bellino S, et al. (2020) Characteristics of COVID-19 patients dying in Italy. Report based on available data on April 2nd, 2020 (PDF) (Report). Istituto Superiore di Sanità. Link: https://bit.ly/2CF8xpq

9. Cheung E (2020) Some recovered Covid-19 patients may have lung damage doctors say. South China Morning Post.

10. WHO team (2020) Draft Landscape of COVID-19 Candidate Vaccines World Health Organization, World Health Organization 29. Link: https://bit.ly/3kT3aV3

11. COVID-19 treatment and vaccine tracker (PDF). Milken Institute. Link: https://bit.ly/34dDWe1

12. Koch S, Pong W (2020) First up for COVID-19: nearly 30 clinical readouts before end of April. BioCentury Inc. Link: https://bit.ly/3gdROax

13. Sanders JM, Monogue ML, Jodlowski TZ, Cutrell JB (2020) Pharmacologic Treatments for Coronavirus Disease 2019 (COVID-19): A Review. JAMA 323: 1824-1836. Link: https://bit.ly/3aCGT92

14. Grenfell R, Drew T (2020) Here's Why It's Taking So Long to Develop a Vaccine for the New Coronavirus. Science Alert. Link: https://bit.ly/3aByhQe

15. Recommendation Regarding the Use of Cloth Face Coverings, Especially in Areas of Significant Community-Based Transmission. U.S. Centers for Disease Control and Prevention (CDC). Link: https://bit.ly/34fNHIG

16. World Health Organization. Advice for Public. Archived from the original on 26 January 2020. Link: https://bit.ly/3aBjoNO

17. Wear masks in public says WHO, in update of COVID-19 advice. Link: https://bit.ly/3hf7efS

18. Cyranoski D (2020) What China's coronavirus response can teach the rest of the world. Nature 579: 479-480. Link: https://bit.ly/2EanWPc

19. Tian H, Liu Y, Li Y, Liu CH, Chen B, et al. (2020) The impact of transmission control measures during the first 50 days of the COVID-19 epidemic in China. medRxiv. Link: https://bit.ly/327dhgf

20. Wells, C (2020) Proc. Natl Acad. Sci. USA. Link: https://doi.org/10.1073/pnas

21. Statistics Bureau Home Page/Population Estimates Monthly Report. Link: https://bit.ly/34hYbrc

22. Contact-tracing and peer pressure: How Japan has controlled coronavirus by Tamoya Saito; 6 June 2020. The GuardianWeekly. Link: https://bit.ly/3j2w9nH 
23. Coronavirus: how japan keeps COVID-19 under control by Martin Fritz (Tokyo), March 25, 2020; Deutsche Welle (DW). Link: https://bit.ly/319YBhd

24. Worldometer's COVID-19 data. Link: https://bit.ly/2CH3eWw

25. WHO | Novel Coronavirus - Japan (ex-China). WHO. Link: https://bit.ly/2FxF8hY

26. Ghinai I, McPherson TD, Hunter JC, Kirking HL, Christiansen D, et al. (2020) First known person-to-person transmission of severe acute respiratory syndrome coronavirus 2 (SARS-CoV-2) in the USA. Lancet 395: 1137-1144. Link: https://bit.ly/2YhBsrr

27. India most infected by Covid-19 among Asian countries, leaves Turkey behind Hindustan Times. 29 May 2020. Link: https://bit.ly/3iYeCgk

28. Coronavírus: Brasil confirma primeiro caso da doença. Ministerio da Saude 26 February 2020. Link: https://bit.ly/34hG6cC

29. Aubrey A (2020) Trump Declares Coronavirus A Public Health Emergency And Restricts Travel From China. NPR. 'Foreign nationals other than immediate family of U.S. citizens and permanent residents who have traveled in China in the last 14 days will be denied entry into United States,' Azar said. Link: https://n.pr/34czs7z

30. Robertson L (2020) Trump's Snowballing China Travel Claim. Link: https://bit.ly/3gdla7R

31. Jonathan L, Zeke M, Jill C, Alonso-Zaldivar R (2020) Signs missed and steps slowed in Trump's pandemic response. Associated Press. Link: https://bit.ly/3geTpgm

32. Ed P, McCarthy T (2020) The missing six weeks: how Trump failed the biggest test of his life. The Guardian. Link: https://bit.ly/31clzDe

33. Ollstein AM (2020) Trump halts funding to World Health Organization. Politico. Link: https://bit.ly/3iP9kU

34. Taylor M (2020) Exclusive: U.S. axed CDC expert job in China months before virus outbreak. Reuters. Link: https://reut.rs/3292K4b

35. Jessica W, Lindsay H, Taylor U, Elbert W, Betsy M (2020) How the CDC's Restrictive Testing Guidelines Hid the Coronavirus Epidemic. The Wall Street Journal. Link: https://on.wsj.com/327yKWr

36. Liptak K (2020) Trump declares national emergency-and denies responsibility for coronavirus testing failures. CNN. Link: https://cnn.it/2E8Qbhl

37. Biesecker M (2020) US 'wasted' months before preparing for coronavirus pandemic. Associated Press. Link: https://bit.ly/3iZLII8

38. US Historical Data (2020) The COVID Tracking Project. Link: https://bit.ly/3gb9pQf

39. Gearan A, DeBonis M, Dennis, Brady (2020) Trump plays down coron- avirus testing as U.S. falls far short of level scientists say is needed. The Washington Post. Link: https://wapo.st/3hegCR7

40. Anne S (2020) Public Health Response to the Initiation and Spread of Pandemic COVID-19 in the United States, February 24 - April 21, 2020. MMWR. Morbidity and Mortality Weekly Report 69: 551-556. Link: https://bit.ly/3/2vqog

41. Withnall A (2020) India to go into nationwide lockdown. The Independent.

42. Lockdown extended till 17 May: What will open, remain closed. Livemint 1 May 2020. Link: https://bit.ly/3I0xdKi

43. 40,000 Indians quarantined after 'super spreader' ignores government advice. Telegraph. 28 March 2020. Link: https://bit.ly/3iXgZjw

44. Coronavirus: India 'super spreader' quarantines 40,000 people. BBC News. 27 March 2020. Link: https://bbc.in/3gih7YR

45. Septuagenarian Sikh priest infected 27 of total 38 coronavirus cases in Punjab. India Today. 28 March 2020. Link: https://bit.ly/3gbbkEl
46. 11 coronavirus suspects in Navi Mumbai traced, readmitted. ANI News 18 March 2020. Link: https://bit.ly/2DZyG37

47. 5 coronavirus suspects escape from isolation ward of Nagpur hospital, al traced. Hindustan Times. 14 March 2020. Link: https://bit.ly/2YdtCPm

48. Sohini G, Vaibhav J (2020) In Gujarat, 93 flouted self-isolation rules in 10 days, FIRs against 10. The Indian Express. Link: https://bit.ly/32eA6Po

49. Passports of two NRIs to be cancelled for violating quarantine orders in Kasaragod. Mathrubhumi. 25 March 2020. Link: https://bit.ly/2YywpTF

50. Coronavirus in India: Mohali woman who travelled to UK tests positive. India Today. Link: https://bit.ly/2FFwkqy

51. Mandetta anuncia em rede social que foi demitido por Bolsonaro do Ministério da Saúde. 16 April 2020. Link: https://glo.bo/3aHYnkz

52. Politics this week. The Economist. 23 April 2020. Link: https://econ.st/2FxVtTQ

53. Saiba quem é Nelson Teich, novo ministro da Saúde. 16 April 2020. Link: https://glo.bo/2EcwOns

54. Elflein J (2020) Covid-19 deaths worldwide as of August 7, 2020, by country.

55. Staff (2020) Updated: Norway announces first case of coronavirus. Link: https://bit.ly/2E87a3m

56. Sondre NA, Leraan SO, Yasmin S, Haug RH, Carina H, et al. Live: Corona-viruset sprer seg i Norge og verden. VG Nett.

57. Pedja K (2020) Alle utdanningsinstitusjoner stenges - flere arrangementer og virksomheter får forbud. NRK (in Norwegian Bokmål).

58. Information in Connection with the Coronavirus (COVID-19). Avinor. 16 March 2020. Retrieved 16 March 2020. From Monday, March 16 at 8:00 a.m. the Government will be closing the border to foreign nationals who lack a residence permit in Norway.

59. Død på sykehjem etter korona-smitte - ytterligere to smittet. nrk.no (in Norwegian). 14 March 2020

60. Information in Connection with the Coronavirus (COVID-19). Avinor. 16 March 2020. From Monday, March 16 at 8:00 a.m. the Government will be closing the border to foreign nationals who lack a residence permit in Norway.

61. Sammendrag: Koronavirus/Summary: Corona virus. NRK.no. Norsk rikskringkasting / Norwegian national broadcasting. Retrieved 21 March 2020

62. Coronavirus epidemic 'under conrrol' in Norway - health minister; World News; April 6, 2020. Link: https://reut.rs/3j1sUwJ

63. Hansen TS, Stephensen EK (2020) Danmark lukker ned: Her er regeringens nye tiltag. TV 2 (in Danish). Link: https://bit.ly/3hfq72

64. Coronavirus: Primi due casi in Italia. Corriere della sera (in Italian). Link: https://bit.ly/2Ekk5Pz

65. Italy suspends all China flights as coronavirus cases confirmed in Rome. The Local. 31 January 2020. Link: https://bit.ly/34gCisf

66. Coronavirus in Italia: aggiornamento ora per ora. la Repubblica (in Italian). 22 February 2020

67. Berberi L (2020) Coronavirus, controlli con gli scanner termici negli aeroporti italiani. Corriere della Sera (in Italian).

68. Yeung J, Renton A, George S (2020) February 6 coronavirus news. CNN. Link: https://cnn.it/325HcFO

69. Codogno, i medici dell'ospedale in trincea: Quelle accuse del premier fanno più male della malattia. la Repubblica (in Italian). 26 February 2020. Link: https://bit.ly/3aDsE40

Citation: Singh AS, Takhellambam MC (2020) COVID-19 pandemic wave: A global struggle and ways to control. Arch Community Med Public Health 6(2): 179-185. 
70. Mailand: Coronavirus-Epidemie begann in Spital. nzz.ch (Neue Zurcher Zeitung).

71. Luna R (2020) Coronavirus: il paziente tedesco. La Repubblica (in Italian) Link: https://bit.ly/2CMdr48

72. What towns in Italy are on lockdown because of coronavirus?. Metro News 25 February 2020

73. L'Italia ha raggiunto il picco, dice I'Istituto Superiore di Sanità. Agi (in Italian) 31 March 2020. Link: https://bit.ly/3aSgbtv

74. Medpage Today; Has Italy beaten COVID-19? - Nation adapts to new normal of masks and distancing; second wave now seen as unlikely.

75. Pandemics That Changed History. History.com. Archived from the original on 2020-03-03. Link: https://bit.ly/34hFwvh

76. Plague of Athens: Another Medical Mystery Solved. at University of Maryland Medical Center. Archived from the original on 2015-12-04. Link: https://bit.ly/3gc1LFp

77. Papagrigorakis MJ, Yapijakis C, Synodinos PN, Baziotopoulou-Valavani E (2007) DNA examination of ancient dental pulp incriminates typhoid fever as a probable cause of the Plague of Athens. International Journal of Infectious Diseases 10: 206-214. Link: https://bit.ly/2EaeAD5

78. Past pandemics that ravaged Europe Archived 2017-10-07 at the Wayback Machine, BBC News.

79. Stathakopoulos DCh (2007) Famine and Pestilence in the late Roman and early Byzantine Empire 95

80. Kyle H (2017) Solving the Mystery of an Ancient Roman Plague. The Atlantic.

81. William R (2007) Justinian's Flea: Plague, Empire, and the Birth of Europe Archived 2017-07-24 at the Wayback Machine. Viking Adult 35: 148. Link: https://bit.ly/34hZDtC

82. Ekonomou A (2007) Byzantine Rome and the Greek Popes. Lexington Books. Link: https://bit.ly/31exilT

83. Thomas M (2020) An Empire's Epidemic. www.ph.ucla.edu. Link: https://bit.ly/2YiJyjh

84. Suzuki A (2011) Smallpox and the epidemiological heritage of modern Japan: Towards a total history. Med Hist 55: 313-318. Link: https://bit.ly/2Yj76Vo

85. George KC (2002) Encyclopedia of Plague and Pestilence: From Ancien Times to the Present. Princeton, New Jersey: Checkmark Books 213. Link: https://bit.ly/2Yhuq5H

86. Suzanne A (2003) A pest in the land: new world epidemics in a global perspective. University of New Mexico Press. 21. Link: https://bit.ly/34fUNNb

87. Acuna-Soto R, Stahle DW, Cleaveland MK, Therrell MD (2002) Megadrought and Megadeath in 16th Century Mexico. Emerg Infect Dis 8: 360-362. Link: https://bit.ly/2E2AlF8

88. American plague. New Scientist. December 19, 2000. Archived from the original on October 17, 2018

89. Acuna-Soto R, Romero LC, Maguire JH (2000) Large epidemics of hemorrhagic fevers in Mexico 1545-1815. Am J Trop Med Hyg 62: 733-739. Link: https://bit.ly/3kYQ7kR

90. Acuna-Soto R, Stahle DW, Cleaveland MK, Therrell MD (2002) Megadrought and Megadeath in $16^{\text {th }}$ Century Mexico. Emerg Infect Dis 8: 360-362. Link: https://bit.ly/3aGjdk6

91. Vågene ÅJ, Herbig A, Campana MG, Robles G, Nelly M, et al. (2018) Salmonella enterica genomes from victims of a major sixteenth-century epidemic in Mexico. Nature Ecology \& Evolution 2: 520-528. Link: https://go.nature.com/329HdbK

92. Scasciamacchia S, Serrecchia L, Giangrossi L, Garofolo G, Balestrucci A, et al. (2012) Plague Epidemic in the Kingdom of Naples, 1656-1658. Emerging Infectious Diseases 18: 186-188. Link: https://bit.ly/32bJeEj

93. Hashemi Shahraki A, Carniel E, Mostafavi E (2016) Plague in Iran: its history and current status. Epidemiol Health 38: e2016033. Link: https://bit.ly/2YhTrOk

94. Hays JN (2005) Epidemics and pandemics: their impacts on human history ABC-CLIO. 236. Link: https://bit.ly/3iWGzVB

95. Pryor EG (1975) The great plague of Hong Kong. Journal of the Hong Kong Branch of the Royal Asiatic Society 15: 61-70. JSTOR Link: https://bit.ly/3gfgz62

96. Stenseth N (2008) Infectious Diseases: Plague Through History. Science 321 773-774. Link: https://bit.ly/2Ykbldl

97. Great Britain. Local Government Board (1893) Further report and papers on epidemic influenza, 1889-92: with an introduction by the medical officer of the Local Government Board. Eyre 49. Link: https://bit.ly/31hNMKd

98. Foster HD, Hoffer A (2007) Chapter 16 - Hyperoxidation of the Two Catecholamines, Dopamine and Adrenaline: Implications for the Etiologies and Treatment of Encephalitis Lethargica, Parkinson's Disease, Multiple Sclerosis, Amyotrophic Lateral Sclerosis, and Schizophrenia. Oxidative Stress and Neurodegenerative Disorders. Elsevier Science B.V: 369-382. Link: https://bit.ly/3g8tEhC

99. Patterson KD, Pyle GF (1991) The geography and mortality of the 1918 influenza pandemic. Bulletin of the History of Medicine 65: 4-2. Link: https://bit.ly/31d1ii0

100. Spreeuwenberg $P$, Kroneman M, Paget J (2018) Reassessing the Global Mortality Burden of the 1918 Influenza Pandemic. American Journal of Epidemiology 187: 2561-2567. Link: https://bit.ly/3iRYKvy

101. Jilani TN, Jamil RT, Siddiqui AH (2020) H1N1 Influenza (Swine Flu). Link: https://bit.ly/34i14lw

102. Patterson KD (1993) Typhus and its control in Russia, 1870-1940. Med Hist 37: 361-381. Link: https://bit.ly/2FH12Q3

103. Paul WE (2008) Fundamental immunology. Lippincott Williams \& Wilkins Link: https://bit.ly/2CMfBkg

104. Report of the Review Committee on the Functioning of the International Health Regulations (2005) in relation to Pandemic (H1N1) 37.

105. Paul WE (2008) Fundamental immunology. Lippincott Williams \& Wilkins Link: https://bit.ly/2CMfBkg

106. Report of the Review Committee on the Functioning of the International Health Regulations (2005) in relation to Pandemic (H1N1) 37.

107. UNAIDS (2010) report on the global AIDS epidemic. Link: https://bit.ly/3hksfWQ

108. Global HIV \& AIDS statistics - 2019 fact sheet. UNAIDS. Link: https://bit.ly/3I2OHpC

Copyright: () 2020 Singh AS, et al. This is an open-access article distributed under the terms of the Creative Commons Attribution License, which permits unrestricted use distribution, and reproduction in any medium, provided the original author and source are credited.

Citation: Singh AS, Takhellambam MC (2020) COVID-19 pandemic wave: A global struggle and ways to control. Arch Community Med Public Health 6(2): 179-185. DOI: https://dx.doi.org/10.17352/2455-5479.000102 